for the purpose. Land on the 250-acre site on which the new Salisbury Native Hospital is being erected will be made available for the needs of a Medical School.

A basic principle in the planning of the site, buildings and facilities will be that there should be no discrimination on racial grounds between categories of students.

Progress has been made in drafting a constitution for the College in a form which will ensure its autonomy. It is the intention to petition Her Majesty the Queen for the University College to be incorporated by Royal Charter.

The Inaugural Board has applied to the University of London for the admission of the College into special relationship with the University. The Senate of London University has signified its willingness to accept the College into this relationship, subject to the receipt of information satisfactory to the University in regard to the constitution and proposed development of the College. Degrees conferred on students of the University College will be those of the University of London, courses at the College being based on syllabuses adapted to local opportunities and needs in consultation between the College itself and the University authorities.

The College will begin by establishing the basic faculties of Arts and Science, and the Principal has already discussed with the University of London requirements for the admission of students to the College and to these faculties. As soon as possible faculties of Agriculture and Medicine will be established.

The initial building and equipment programme, staffing and other preparations will take at least two years to complete, but every effort will be made to open the College for teaching by March 1956 .

\title{
Archaeological Museum in the Gold Coast
}

A GRowING and eager interest in its own past is being manifested in the Gold Coast, evidence of which may be found in the activities of the Gold Coast and Togoland historical society (see Africa, xxiv. 2, pp. 163-4) and in the reception given to the lecture delivered at Cape Coast in April last by Professor Lawrence, Professor of Archaeology in the University of the Gold Coast. Interest in archaeology is being stimulated and guided by the development of the National Museum of the Gold Coast, in connexion with which a large archaeological museum is to be built next year in Accra, while museums at Kumasi and Tamale are planned. In the meantime the research museum at Legon, near Accra, has been opened to the public. The National Museum during the three years of its existence has accumulated many objects of interest; though very little systematic excavation has so far been attempted in the Gold Coast, the collections have twice outgrown the space allotted to them. The scope of the National Museum is wide: it is to illustrate what man has achieved in all Africa. The ancient civilizations of North Africa are treated so amply, in view of their known or suspected relations with West Africa, that there are many valuable exhibits of Greek, Roman, and Egyptian origin. Recent cultures of other parts of Africa are illustrated by works of artistic interest. The contents of the museum of Achimota School (consisting of some 5,000 objects of Gold Coast origin as well as material from Nigeria) were transferred to the Museum in 1953. Excavations in the Gold Coast have yielded a great quantity of Iron Age and Stone Age implements as well as baked-clay statuettes, some of them of distinct artistic merit. The museum has also been the recipient of gifts from English museums as well as from private collections.

\section{Pan-African Congress on Prehistory}

THE third meeting of the Pan-African Congress on Prehistory will be held in Livingstone, Northern Rhodesia, in July I955, at the invitation of the Northern Rhodesia Government, 